\title{
¿El estilo de liderazgo de los administradores escolares afecta la gestión de conflictos?
}

\section{Does leadership style of school administrators affect conflict management?}

\author{
Muammer Maral ${ }^{1 \mathrm{a}}$, Mehmet Ali Hamedoğlu² \\ Marmara University, Institute of Educational Sciences, Turquía ${ }^{1}$ \\ Sakarya University, Faculty of Education, Turquía ${ }^{2}$ \\ ORCID ID: https://orcid.org/0000-0002-2055-5711 \\ (iD) ORCID ID: https://orcid.org/0000-0003-2833-2931 2
}

Recibido: 15 de junio de 2021

Aceptado: 24 setiembre de 2021

\section{Resumen}

Este estudio tiene como objetivo examinar los efectos de los estilos de liderazgo de los administradores escolares en las estrategias de manejo de conflictos. Esta investigación fue diseñada como un modelo correlacional. La muestra del estudio consta de 365 maestros y administradores escolares que trabajan en escuelas primarias, secundarias y secundarias públicas en el distrito de Kağıthane de la provincia de İstanbul. Se utilizaron el Inventario de conflictos organizacionales de Rahim y la Escala de liderazgo multifactorial para la recopilación de datos. De acuerdo con los hallazgos del estudio, entre los estilos de liderazgo, los administradores escolares exhiben el estilo de liderazgo transformacional más y el estilo de liderazgo laissez faire menos; entre las estrategias de manejo de conflictos, exhiben la estrategia integradora y comprometedora la más y la estrategia dominante la menos. El estilo de liderazgo transformacional predice de manera positiva la estrategia de integración, compromiso, obligación y evitación, mientras que predice la estrategia dominante de manera negativa. La única estrategia predicha por el liderazgo transaccional es la estrategia dominante, y predice positivamente. El liderazgo de Laissez Faire predice negativamente la estrategia de integración y compromiso, mientras que predice positivamente la estrategia dominante. Los comportamientos de liderazgo transformacional de los administradores escolares les permitirán manejar los conflictos de manera efectiva. En suma, el liderazgo transaccional y los estilos de liderazgo laissez faire resultarán en una gestión de conflictos que tendrá efectos devastadores en las personas y las organizaciones.

Palabras clave: Educación, administración educativa, liderazgo, manejo de conflictos.

${ }^{\mathrm{a} C}$ Correpondencia al autor

E-mail: muammermaral@ hotmail.com

This article is an expanded version of the master's thesis prepared by the first author under the supervision of the second author at Sakarya University Institute of Educational Sciences 


\begin{abstract}
This study aims to examine the effects of school administrators' leadership styles on conflict management strategies. This research was designed as a correlational model. The sample of the study consists of 365 teachers and school administrators working in public primary, secondary and high schools in Kağıthane district of Istanbul province. Rahim Organizational Conflict Inventory and Multifactor Leadership Scale were used for data collection. According to the findings of the study, among the leadership styles, school administrators exhibit the transformational leadership style the most and laissez faire leadership style the least; among the conflict management strategies, they exhibit integrating and compromising strategy the most and dominating strategy the least. Transformational leadership style positively predicts integration, compromising, obliging, and avoiding strategy while it predicts the dominating strategy negatively. The only strategy predicted by transactional leadership is the dominating strategy, and it predicts positively. Laissez Faire Leadership negatively predicts the integration and compromising strategy while it positively predicts the dominating strategy. School administrators' transformational leadership behaviors will enable them to manage conflicts effectively. In sum, Transactional leadership and laissez faire leadership styles will result in conflict management that has devastating effects on individuals and organizations.
\end{abstract}

Keywords: Education, Education Administration, Leadership, Conflict Management

\title{
Introduction
}

Conflict is an inevitable part in organizational life (Rahim, 2017) and there are different definitions in the literature regarding the concept of conflict. According to Robbins (1974), conflict is the opposition and mutual negative relationship of individuals towards each other, and they are based on power, resources, low social position, and value judgments. According to Rahim (2002), conflict is an interactive process that occurs in the form of incompatibility and disagreement between and within social entities.

According to the traditional view, conflict is always negative and harmful for both the individual and the organization (Robbins, 1998); and they should be blocked in all situations, their occurrence should be prevented (Tosi, Rizzo, \& Carroll, 1994). According to the human relations approach, conflict is an inevitable situation that occurs spontaneously in organizations and it is possible to experience a certain level of conflict in the organization (Kolb \& Putnam, 1992). According to the interactionist approach, a certain level of conflict must exist in order to increase the efficiency and performance of the organization (Tosi et al., 1994).

Current debates about conflicts are that conflicts should be managed. The concept of conflict management refers to the ability to keep the conflict at a functional level that will benefit a department, work unit, or organization as a whole. Conflict management does not refer to the elimination or reduction of conflict (De Dreu, 1997; Jehn \& Bendersky, 2003). Conflict 
management means that managers create a conflict environment or reduce the level of conflict in the organization when necessary (Champoux, 2020).

Different strategies for managing conflicts have been proposed in the literature (Amason, 1996; Gordon, 1996; Jehn, Northcraft, \& Neale, 1999; Rahim, 2001). One of these was put forward by Rahim (2001), who suggests five different strategies: integrating, compromising, obliging, avoiding, and dominating. Integrating strategy implies information exchange and cooperation in order to reach a solution acceptable to all parties; compromising strategy implies making sacrifices to meet the other party's concerns; dominating strategy implies the strong side should ignore the interests and aspirations of the other side and use its power to win the conflict; avoiding strategy implies postponing the conflict situation, ignoring and avoiding the conflict; compromising strategy, on the other hand, implies the sacrifice of both sides and finding a middle ground.

In many studies conducted in educational organizations, it was revealed that school administrators mostly used the integrating and compromising strategy (Akbaba \& Erberk, 2015; Çimen \& Sarıboğa, 2020; Donovan, 1993; Gül \& Türkmen, 2018; Konak \& Erdem, 2015; Okçu, Doğan, \& Dayanan, 2018; Önk \& Cemaloğlu, 2016; Örs \& İlgar, 2019; Şanlı Güneş \& Akbaba, 2020; Titrek, Maral, \& Barut-Kiz1lkaya, 2015). It is concluded that the least preferred strategy is the dominating strategy (Akbaba \& Erberk, 2015; Çelik \& Tosun, 2019; Donovan, 1993; Gül \& Türkmen, 2018; Konak \& Erdem, 2015; Okcu, Dogan, \& Dayanan, 2016; Okçu et al., 2018; Önk \& Cemaloğlu, 2016; Örs \& İlgar, 2019; Şanlı Güneş \& Akbaba, 2020; Titrek et al., 2015).

According to Önk and Cemaloğlu (2016), there are many factors that affect managers' conflict management strategies. Leadership is also one of the most important variables affecting conflict management. There are studies in the literature that have been conducted considering this effect. Polatc1 and Sobac1 (2017), examined conflict management's relationship with transformational and transactional leadership, Çiftci and Erkanlı (2020) with task-oriented and people-oriented leadership, Jit, Sharma, and Kawatra (2016) with servant leadership, Ayda et al. (2020) with paternalist leadership, and Msila (2012), Zhang, Cao, and Tjasvold (2011) with transformational leadership.

Considering the studies conducted in educational organizations by Arslantaş and Özkan (2012), Korkmaz and Çağlı (2019), Örs and İlgar (2019), Doğan (2012), Saeed, Almas, Anisul-Haq, and Niazi (2014), Önk and Cemaloğlu (2016) and Chandolia and Anastasiou (2020), it was concluded that there is a significant relationship between managers' leadership styles and conflict management strategies. 
In most of the studies, the correlation between leadership styles and conflict management strategies has been examined. Studies based on inferential analysis revealing the effect of leadership on conflict management are considerably limited. The fact that leadership has a positive or negative relationship with conflict management strategies does not mean that leadership has an effect on conflict management. In short, the relationship does not prove the existence of the effect. Therefore, in this study, it will be tested whether leadership significantly predicts conflict management or not. In addition, empirical studies in the field of educational management are limited and more empirical studies are needed. Existing studies have generally been carried out on a limited type of school. This study will diversify the literature by including teachers and administrators working in primary, secondary and high schools. It is thought that this study will contribute to the field of education management due to the mentioned circumstances.

Also, the purpose of this study is to examine the effects of school administrators' leadership styles on conflict management strategies. For this purpose, answers will be sought for the following questions .

1. To what extent do school administrators display their leadership styles and conflict management strategies?

2. Is there a statistically significant relationship between leadership styles and conflict management strategies?

3. Are leadership styles a significant predictor of conflict management strategies?

\section{Method}

\section{Research design}

This research is based on the correlational model. According to Creswell (2012), the correlational model is a research model that allows us to explain the relationship between variables and predict scores.

\section{Research sample}

The population of the study consists of 2,100 teachers and school administrators working in public primary, secondary and high schools in the district of Kağıthane in Istanbul province. The sampling method used in the study is the proportional cluster sampling method. Cohen's (1988) formula was used in determining the sample size. Using the formula valid for situations when the number of individuals in the population was known before, 322 participants were determined as the lower limit at a $95 \%$ confidence interval. The sample of the study consists of 
365 teachers and administrators. 212 of the participants are women (58.1\%), 153 of them are men (41.9\%). $101(27.7 \%)$ of the participants work in primary school, $198(54.2 \%)$ in secondary school, $66(18.1 \%)$ in high school.

\section{Research instruments and procedures}

The "Demographic Information Form" developed by the researchers was used to collect the demographic information of the participants such as age, gender, and type of school they work. The "Rahim Organizational Conflict Inventory", developed by Rahim (1983) and adapted into Turkish by Gümüşeli (1994), was used in collecting data on managers' conflict management strategies. The scale is a 5-point Likert type scale consisting of 28 items and 5 dimensions (integrating, obliging, avoiding, compromising, dominating). The scale is scored as 1=very rarely, $2=$ rarely, $3=$ sometimes, 4=often, 5=always. Originally, the Cronbach Alpha reliability coefficients for the dimensions of the scale were between 0.72 and 0.75 . In this study, the Cronbach Alpha reliability coefficient for the whole scale was found to be 0.85 .

"Multifactor Leadership Scale" developed by Bass (1985) and adapted into Turkish by Akdoğan (2002) was used to collect data on the leadership styles of managers. The scale is a 5point Likert type scale consisting of three dimensions: transformational leadership, transactional leadership, and laissez faire leadership. The scale is scored as $1=$ never, $2=$ rarely, 3=sometimes, 4=often, 5=always. The Cronbach Alpha reliability coefficient for the whole scale was found as 0.92 by Akdoğan (2002). In this study, the Cronbach Alpha reliability coefficient for the whole scale was found to be 0.85 . The data were collected in about one month in 2016. The scales were distributed to 750 people and a total of 380 were answered. 365 of them were evaluated.

\section{Data analysis}

Descriptive statistics such as percentage, frequency, and standard deviation were used in the data analysis, the Pearson's Product Moment Correlation Method in the correlation analysis, and the Multiple Linear Regression Analysis in inferential analyzes that reveal the effect of independent variables on dependent variables. The obtained results were tested at $\mathrm{p}<0.05$ and $\mathrm{p}<0.01$ levels. Data were analyzed with SPSS 22.0 package program.

The data were examined before they were analyzed and it was tested whether the data satisfied the assumptions required for the statistical analysis. According to Tabachnick and 
Fidell (2013), the skewness and kurtosis coefficients between -1.50 and +1.50 show that the data are normally distributed. It was found in the analysis that the skewness coefficients for conflict management strategies ranged from 0.695 to -0.809 and for leadership styles from 0.727 to 0.484 . Parametric tests were used in the analysis since the data was normally distributed.

It was seen that the following four assumptions (Can, 2014) required for performing Multiple Linear Regression Analysis were satisfied in the analyses. (1) Data are at least in range scale and normally distributed. (2) The linearity relationship between the predictor variables and the predicted variables was examined, and it was observed that the linearity assumption was satisfied, except for the relationship between laissez faire leadership and avoiding strategy ( $p>0.05, r=0.012$ ). For this reason, laissez faire leadership was excluded from the regression analysis in predicting the avoiding strategy. (3) It was found that the predictor variables were not highly correlated with each other, which means there was no multicollinearity problem ( $\mathrm{p}<0.01)$. The results are given in Table-2. (4) According to Field (2005) and Morgan, Leech, and Barret (2005), the random scattering of the points on the scatter plot around the 0 value indicates that the error has a normal distribution. In the scatter plot, the points are randomly distributed around the 0 value. Graphics are given in Figure-1.

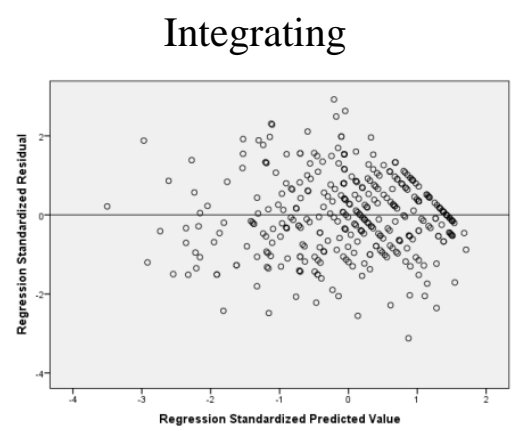

Dominating

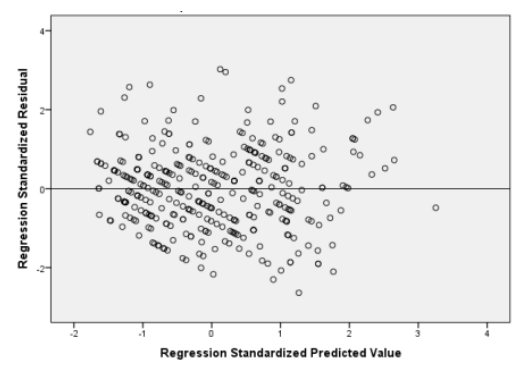

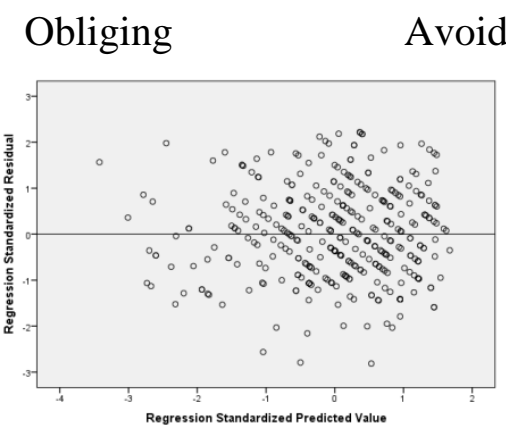

Compromising

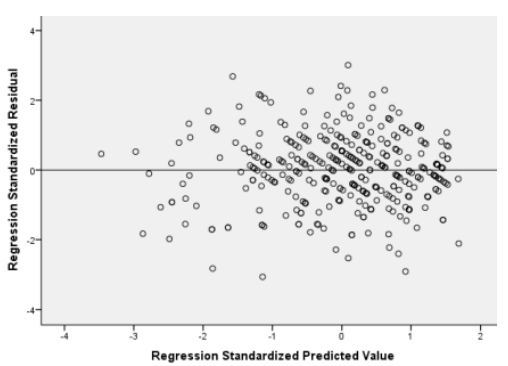

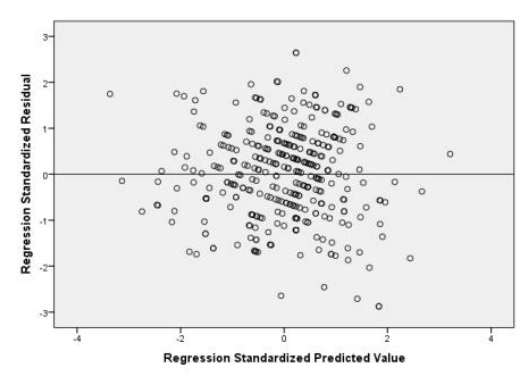

Regression Standardized Predicted Va

Figure 1. Scatter plots of estimated standardized values and standardized outliers 
In interpreting the leadership styles and conflict management styles of managers, 1.00-1.80 "very low," 1.81-2.60 "low," 2.61-3.40 "medium," 3.41-4.20 "high," and 4.21-5.00 “very high" score ranges were used. The interpretation formula of Dancey and Reidy (2007) was used in interpreting the correlation coefficients. Accordingly, $r=0$ no relationship, $\pm 0.10 \leq r< \pm 0.40$ weak relationship, $\pm 0.40 \leq \mathrm{r} \pm 0.70$ moderate relationship, $\pm 0.70 \leq \mathrm{r} 1$ strong relationship, and $\mathrm{r}=1$ perfect relationship values were taken as basis.

\section{Findings}

The first subgoal of the study is related to the level of leadership styles and conflict management strategies that school administrators exhibit. The findings obtained for this purpose are given in Table 1.

\section{Table 1}

Level of exhibition of school administrators' leadership styles and conflict management strategies

\begin{tabular}{lccc}
\hline & $\mathbf{N}$ & $\overline{\mathbf{X}}$ & Sd \\
\hline Transformational Leadership & 365 & 3.77 & 0.73 \\
Transactional Leadership & 365 & 3.46 & 0.44 \\
Laissez Faire Leadership & 365 & 2.05 & 0.84 \\
Integrating & 365 & 3.86 & 0.91 \\
Compromising & 365 & 3.58 & 0.76 \\
Obliging & 365 & 3.19 & 0.80 \\
Avoiding & 365 & 3.06 & 0.69 \\
Dominating & 365 & 2.30 & 0.82 \\
\hline
\end{tabular}

According to the findings of the study, school administrators exhibit transformational leadership ( $\overline{\mathrm{X}}=3.77)$ and transactional leadership ( $\overline{\mathrm{X}}=3.46)$ style at a high level, and laissez faire leadership style $(\overline{\mathrm{X}}=2.05)$ at a low level. School administrators exhibit transformational leadership style the most and laissez faire leadership style the least.

School administrators exhibit integrating $(\overline{\mathrm{X}}=3.86)$ and compromising strategies $(\overline{\mathrm{X}}=3.58)$ at a high level, obliging $(\overline{\mathrm{X}}=3.19)$ and avoiding strategies $(\overline{\mathrm{X}}=3.06)$ at a medium level, and dominating strategy $(\overline{\mathrm{X}}=2.30)$ at a low level. School administrators exhibit the strategy of integrating and compromising the most and the strategy of dominating the least. The second 
subgoal of the study is to determine the relationship between school administrators' leadership styles and conflict management strategies. Findings for this purpose are given in Table 2.

Table 2

The relationship between leadership styles and conflict management strategies

\begin{tabular}{lllllllll}
\hline & $\mathbf{1}$ & $\mathbf{2}$ & $\mathbf{3}$ & $\mathbf{4}$ & $\mathbf{5}$ & $\mathbf{6}$ & $\mathbf{7}$ & $\mathbf{8}$ \\
\hline Integr. & 1 & & & & & & \\
Compr. & $0.884^{* * *}$ & 1 & & & & & \\
Obliging & $0.792^{* *}$ & $0.805^{* *}$ & 1 & & & & \\
Avoid. & $0.267^{* *}$ & $0.368^{* *}$ & $0.370^{* *}$ & 1 & & & & \\
Domin. & $-0.573^{* *}$ & $-0.489^{* *}$ & $-0.367^{* *}$ & 0.016 & 1 & & \\
Tranf.L. & $0.861^{* *}$ & $0.802^{* *}$ & $0.743^{* *}$ & $0.290^{* *}$ & $-0.536^{* *}$ & 1 & \\
Tranc.L. & $0.600^{* *}$ & $0.565^{* *}$ & $0.487^{* *}$ & $0.243^{* *}$ & $-0.285^{* *}$ & $0.665^{* *}$ & 1 & \\
Laissez & $-0.604^{* *}$ & $-0.509^{* *}$ & $-0.399^{* *}$ & 0.012 & $0.620^{* *}$ & $-0.558^{* *}$ & $-0.434^{* *}$ & 1 \\
\hline p $<.05 * * \mathrm{p}<.01$ & & & & & & &
\end{tabular}

According to Pearson's Product Moment Correlation technique analysis results, transformational leadership have positive strong relationship with integrating $(r=0.861, p$ $<.01)$, with compromising $(\mathrm{r}=0.802, \mathrm{p}<.01)$, and with obliging strategy $(\mathrm{r}=0.743, \mathrm{p}<.01)$; it has positive weak relationship with avoiding strategy $(\mathrm{r}=0.290, \mathrm{p}<.01)$, and it has negative moderate relationship with dominating strategy $(\mathrm{r}=-0.536, \mathrm{p}<.01)$. Transactional leadership hasa positive and moderate relationship with integrating $(r=0.600, p<.01)$, with compromising $(\mathrm{r}=0.565, \mathrm{p}<.01)$, and with obliging strategy $(\mathrm{r}=0.487, \mathrm{p}<.01)$; it has a positive weak relationship with avoiding strategy $(\mathrm{r}=0.243, \mathrm{p}<.01)$ and negative weak relationship with dominating strategy $(\mathrm{r}=-0.536, \mathrm{p}<.01)$.

For the other hand, laissez faire leadership has a negative and moderate relationship with integrating $(\mathrm{r}=-0.604, \mathrm{p}<.01)$ and compromising strategy $(\mathrm{r}=-0.509, \mathrm{p}<.01)$; it has a negative weak relationship with obliging strategy $(r=-0.399$, p.<01), and a positive moderate relationship with dominating strategy $(r=0.620, p<.01)$ whereas it does not have any significant relationship with avoiding strategy. The third subgoal of the research is related to whether leadership styles are significant predictors of conflict management strategies. Multiple Linear Regression Analysis results performed for this purpose are given in Table-3. 
Table 3

Results of multiple linear regression analysis

\begin{tabular}{|c|c|c|c|c|c|c|c|c|}
\hline $\begin{array}{l}\text { Dependent } \\
\text { Variable }\end{array}$ & Predictor Variable & B & $\mathrm{SH}$ & $\beta$ & $\mathrm{T}$ & $\mathrm{p}$ & $\begin{array}{c}\text { Bivariate } \\
\mathrm{r}\end{array}$ & $\begin{array}{c}\text { Partial } \\
\text { r }\end{array}$ \\
\hline \multirow{7}{*}{ 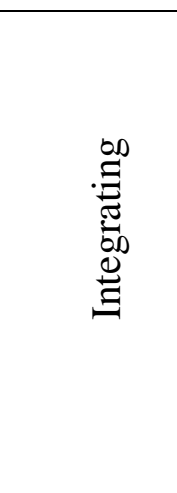 } & Constant & 0.53 & 0.24 & & 2.13 & 0.03 & & \\
\hline & Transf.L. & 0.92 & 0.04 & 0.74 & 19.8 & $0.00 * *$ & 0,86 & 0.72 \\
\hline & Transac. L. & 0.06 & 0.07 & 0.03 & 0.91 & 0.36 & 0.60 & 0.049 \\
\hline & Laissez F.L. & -0.19 & 0.03 & -0.17 & -5.67 & $0.00 * *$ & -0.60 & -0.29 \\
\hline & $\mathrm{R}=0.874$ & $\mathrm{R}^{2}=0.763$ & & & & & & \\
\hline & $\mathrm{F}_{(3-361)}=387.662$ & $\mathrm{p}=0,000$ & & & & & & \\
\hline & Constant & 0.61 & 0.25 & & 2.427 & 0.01 & & \\
\hline \multirow{7}{*}{ 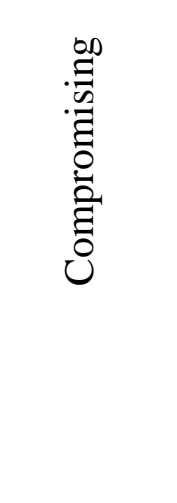 } & Transf.L. & 0.75 & 0.05 & 0.72 & 15.87 & $0.00 * *$ & 0.80 & 0.64 \\
\hline & Transac. L. & 0.08 & 0.07 & 0.05 & 1.16 & 0.25 & 0.57 & 0.06 \\
\hline & Laissez F.L. & -0.08 & 0.03 & -0.09 & -2.25 & $0.03 *$ & -0.51 & -0.12 \\
\hline & $\mathrm{R}=0.806$ & $\mathrm{R}^{2}=0.650$ & & & & & & \\
\hline & $\mathrm{F}_{(3-361)}=223.250$ & $\mathrm{p}=0,000$ & & & & & & \\
\hline & Constant & 0.07 & 0.30 & & 0.23 & 0.82 & & \\
\hline & Transf.L. & 0.84 & 0.06 & 0.76 & 14.83 & $0.00 * *$ & 0.74 & 0.62 \\
\hline \multirow{5}{*}{ 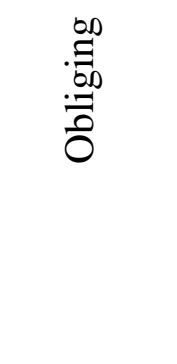 } & Transac. L. & -0.02 & 0.09 & -0.01 & -0.23 & 0.82 & 0.49 & -0.01 \\
\hline & Laissez F.L. & 0.02 & 0.04 & 0.02 & 0.51 & 0.61 & -0.40 & 0.03 \\
\hline & $\mathrm{R}=0.744$ & $\mathrm{R}^{2}=0.553$ & & & & & & \\
\hline & $\mathrm{F}_{(3-361)}=148.775$ & $\mathrm{p}=0,000$ & & & & & & \\
\hline & Constant & 1.17 & 0.28 & & 6.29 & 0.00 & & \\
\hline \multirow{5}{*}{ 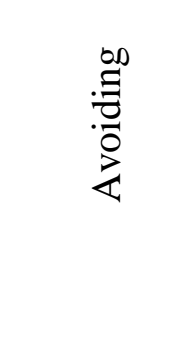 } & Transf.L. & 0.22 & 0.06 & 0.23 & 3.42 & $0.01 *$ & 0.18 & 0.17 \\
\hline & Transac. L. & 0.14 & 0.11 & 0.09 & 1.35 & 0.18 & 0.07 & 0.07 \\
\hline & $\mathrm{R}=0.368$ & $\mathrm{R}^{2}=0.136$ & & & & & & \\
\hline & $F_{(3-361)}=18.893$ & $\mathrm{p}=0,000$ & & & & & & \\
\hline & Constant & 1.80 & 0.34 & & 5.36 & 0.00 & & \\
\hline \multirow{6}{*}{ 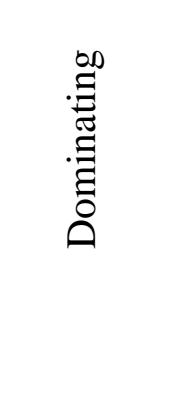 } & Transf.L. & -0.43 & 0.06 & -0.39 & $-6,84$ & $0.00 * *$ & -0.54 & -0.34 \\
\hline & Transac. L. & 0.34 & 0.10 & 0.18 & 3.48 & $0.00 * *$ & -0.29 & 0.18 \\
\hline & Laissez F.L. & 0.47 & 0.05 & 0.48 & 10.24 & $0.00 * *$ & 0.62 & 0.47 \\
\hline & $\mathrm{R}=0.675$ & $\mathrm{R}^{2}=0.455$ & & & & & & \\
\hline & $F_{(3-361)}=100.477$ & $\mathrm{p}=0,000$ & & & & & & \\
\hline & $\mathrm{N}=365$ & $\mathrm{p}<0.05$ & $* * \mathrm{p}$ & .01 & & & & \\
\hline
\end{tabular}


As a result of five different multiple linear regression analyses, transformational leadership, transactional leadership, and laissez faire leadership showed a significant relationship $\left(R=0.874, R^{2}=0.763\right)$ with the integration strategy $\left(F_{(3-361)}=387.662, p<0.01\right)$. These three mentioned variables together explain $76 \%$ of the changes in the integrating strategy. Considering the significance tests of the regression coefficients, transformational leadership $(\beta=0.74, p<0.01)$ and laissez faire leadership $(\beta=-0.17, p 0.01)$ from predictor variables were found to be significant predictors of the integrating strategy.

According to the result of the second regression analysis, transformational leadership, transactional leadership, and laissez faire leadership showed a significant relationship $(\mathrm{R}=$ $\left.0.806, \mathrm{R}^{2}=0.650\right)$ with the compromising strategy $\left(\mathrm{F}_{(3-361)}=223.250, \mathrm{p}<0.01\right)$. These three mentioned variables together explain $65 \%$ of the changes in the compromising strategy. Considering the significance tests of the regression coefficients, transformational leadership $(\beta=0.72, p<0.01)$ and laissez faire leadership $(\beta=-0.09, \mathrm{p} 0.05)$ from predictor variables were found to be significant predictors of the compromising strategy.

According to the result of the third regression analysis, transformational leadership, transactional leadership, and laissez faire leadership showed a significant relationship ( $\mathrm{R}$ $\left.=0.744, \mathrm{R}^{2}=0.553\right)$ with the obliging strategy $\left(\mathrm{F}_{(3-361)}=148.775, \mathrm{p}<0.01\right)$. These three mentioned variables together explain $55 \%$ of the changes in the obliging strategy. Considering the significance tests of the regression coefficients, only transformational leadership $(\beta=0.76$, $\mathrm{p}<0.01)$ from predictor variables were found to be a significant predictor of the obliging strategy.

According to the result of the fourth regression analysis, transformational and transactional leadership displayed a significant relationship $\left(\mathrm{R}=0.368, \mathrm{R}^{2}=0.136\right)$ with the avoiding strategy $\left(\mathrm{F}_{(3-361)}=18.893, \mathrm{p}<0.01\right)$. These two mentioned variables together explain $13 \%$ of the changes in the avoiding strategy. Considering the significance tests of the regression coefficients, only transformational leadership $(\beta=0.23, \mathrm{p}<0.05)$ from predictor variables were found to be a significant predictor of the avoiding strategy.

According to the result of the fifth regression analysis, transformational leadership, transactional leadership, and laissez faire leadership showed a significant relationship $\left(\mathrm{R}=0.675, \mathrm{R}^{2}=0.455\right)$ with the dominating strategy $\left(\mathrm{F}_{(3-361)}=100.477, \mathrm{p}<0.01\right)$. These three mentioned variables together explain $45 \%$ of the changes in the dominating strategy. Considering the significance tests of the regression coefficients, transformational leadership $(\beta=-0.39, \mathrm{p}<0.01)$, transactional leadership $(\beta=0.18, \mathrm{p} 0.01)$ and laissez faire leadership $(\beta=0.48$, 
p0.01) from predictor variables were found to be significant predictors of the dominating strategy.

\section{Discussion}

The aim of this study is to examine whether the leadership styles of school administrators are significant predictors of conflict management strategies. Descriptive statistics, correlation analysis, and multiple linear regression analysis were used to achieve this aim. According to the findings of the study, school administrators exhibit the strategies of integrating and compromising the most and the strategy of dominating the least. Findings of the study are parallel to the findings of Konak and Erdem (2015), Örs and İlgar (2019), Çimen and Sarıboğa (2020), Titrek et al. (2015), Okcu et al. (2016), Şanlı Güneş and Akbaba (2020), Akbaba and Erberk (2015), Önk and Cemaloğlu (2016), Donovan (1993), Okçu et al. (2018), and Gül and Türkmen (2018). However, they contrast with the findings of Demirdağ (2016), Chandolia and Anastasiou (2020), Çelik and Tosun (2019), Saeed et al. (2014), and Küçüksüleymanoğlu and Bingöl (2014).

According to Karip (2013), the parties deal with the problem by cooperating in the integrating approach. The true causes of the problem are presented in a constructive manner, and it is aimed to satisfy the interests and needs of both parties. According to this result of the study, school administrators aim to resolve conflicts within the framework of cooperation and compromise rather than dominating others and suppressing individuals. This can be due to the school administrators' aim for the educational environment to function in a healthy way. Because, according to Mishra and Dhar (2002), poorly managed conflicts cause further escalation of tensions between the parties, deteriorate communication, and damage the organization itself.

According to the other finding of the study, school administrators exhibit among the leadership styles the transformational leadership style the most, and laissez faire leadership style the least. While this finding of the study, is parallel to studies of Saeed et al. (2014), Önk and Cemaloğlu (2016), Korkmaz and Çağlı (2019), Ermeydan and Can (2020), it is in contrast with the study of Kavrayıc1 (2019). According to Yukl (2013), transformational leaders support individuals, encourage and guide them. Moreover, these leaders put forward a common vision and strive for common purposes with their employees without pursuing mutual benefit. This result of the research can be interpreted as school administrators encourage and inspire employees as a leader and create an impact in the school in order to ensure that the aims and objectives of education are carried out with a joint effort. 
According to the other finding of the study, it was concluded that transformational and laissez faire leadership is a significant predictor of the integrating and compromising strategy. Transformational leadership style causes a positive effect in these two strategies while laissez faire leadership causes a negative effect. This finding of the research is parallel to the research findings of Korkmaz and Çağlı (2019) and Önk and Cemaloğlu (2016). The leadership style with the highest impact on the integrating strategy is transformational leadership. Study findings of Şirin (2008), Geçmez (2009), Saeed et al. (2014), and Önk and Cemaloğlu (2016) support this finding. Transformational leaders make individuals believe in achieving their goals without hindering each other's wishes. Individuals tend to be less competitive when facing conflict. Because transformational leadership does not encourage such behaviors (Zhang et al., 2011). Therefore, school administrators who exhibit transformational leadership generally manage conflicts with integrating and compromising styles that are constructive. Contrary to expectations, school administrators who exhibit laisse faire leadership do not remain indifferent to conflict situations and approach conflicts with the strategy of dominating.

According to another finding for the third sub-aim of the study, the only variable that significantly predicts the obliging and avoiding strategy is transformational leadership. Transformational leadership has a positive effect on the obliging and avoiding strategy. Saeed et al. (2014) and Önk and Cemaloğlu (2016) also found in their research that transformational leadership predicts the obliging strategy. Önk and Cemaloğlu (2016) found in their study that transformational leadership is a significant predictor of obliging and avoiding strategy. These studies are parallel to the findings of the research. The obliging strategy is a strategy in which the interests and demands of the other party gain importance while the avoiding strategy is the one in which the handling of the conflict is delayed.

According to Lunenburg and Ornstein (2021), leaders support individuals and make them feel valuable in transformational leadership through its intellectual stimulation and caring individuals behavior dimensions. In addition, transformational leaders support individuals to be more creative (Jung, 2001). They allow them to look at the problems from a new perspective (Bass \& Avolio, 1990) and put the needs of others above their own (Avolio, 1994). It is natural for school administrators who exhibit transformational leadership to prefer an obliging strategy that will highlight the demands of individuals in conflict situations. In addition, it is possible for school administrators to use the avoiding strategy for a brief period to give individuals the time to put forward creative ideas on the problem that causes conflict.

According to another finding related to the third subgoal, all three leadership styles significantly predict the dominating strategy. Transformational leadership style has a negative 
effect on the dominating strategy. This finding of the research is parallel to Saeed et al. (2014)'s research findings. In addition, transactional and laissez faire leadership have a positive effect on the dominating strategy. While this finding of the study is in line with the research findings of Önk and Cemaloğlu (2016) and Korkmaz and Çağl1 (2019), it is in contrast with the research findings of Saeed et al.(2014). Saeed et al. (2014) found that transactional leadership significantly predicted the dominating strategy in a negative way. Transformational leaders create trust and respect in employees, inspire admiration, are respected by employees, and employees trust these leaders (Avolio, 1994). Transformational leaders energize people (Bass \& Avolio, 1994) and consider individual importance (Hoy \& Miskel, 2005). It can be said that school administrators who exhibit transformational leadership stay away from the dominating strategy in which one side uses its power over the other side and the interests and wishes of the other side are ignored.

Transactional leaders insist individuals be appropriate to standards. That is, leaders follow current performance and intervene immediately when problems arise (Hoy \& Miskel, 2005). These leaders award according to the work done and performance. Maintaining the status quo is important for these leaders (Bass \& Avolio, 1994). Leaders motivate individuals with rewards and punishments (Kuhnert, 1994). Therefore, it is possible to talk about the tendency of school administrators who exhibit transactional leadership to use force when necessary as an element of pressure. It can be thought that these leaders want to prevent the conflict from harming the organization by using the strategy of dominating in conflict situations in order for the status quo to function properly.

According to the findings of the research, it is the laissez faire leadership that has the highest impact on the dominating strategy. The studies of Önk and Cemaloğlu (2016), Şirin (2008), and Geçmez (2009) support this finding. On the other hand, it was concluded that transactional leadership is only a significant predictor of the dominating strategy. This finding of the research contrasts with the findings of Saeed et al. (2014) research, who found that transactional leadership significantly predicts compromising strategy. According to Bass (1998), laissez faire leadership means avoiding responsibility and not interacting with employees. Such leaders are not expected to use the dominating strategy. This finding of the study might have resulted from the effect of school administrators' indifference to individuals in conflict situations. The behavior of the school administrator, who ignores their interests and needs in case of conflict, might have caused an oppressive perception in individuals.

The first limitation of this study is that the responses to the scales are based on the perceptions of school administrators and teachers. Because what the participants experienced 
in those days when they answered the scales may have caused them to evaluate their managers with bias. The second limitation is that it covers teachers and administrators working in only one district and only public schools.

\section{Conclusion}

School administrators' behaviors of transactional and laissez faire leadership will prevent the effective management of conflicts. Therefore, managers need to stay away from transactional and laissez faire leadership behaviors in order to manage conflicts more effectively. Moreover, school administrators are required to exhibit transformational leadership behaviors. This will enable conflicts to be managed more effectively in school. In order to create awareness in administrators, conflict management trainings that would provide school administrators with transformational leadership skills and introduce transactional leadership and laissez faire leadership styles should be planned.

The trainings to be made should be planned in a scientific framework. From a scientific point of view, school administrators should be made aware in these trainings of how their leadership behavior and conflict management strategies will affect the school. This study can be expanded to include private schools and public schools, and a comparison of public and private schools can be made. In addition, a mixed method research can be designed to address conflict management in more depth.

\section{References}

Akbaba, A., \& Erberk, E. (2015). İlk ve ortaokul müdürlerinin çatışma yönetim stratejilerine ilişkin öğretmen algıları [Teachers' perceptions about conflict management strategies of school administrators]. The Journal of Academic Social Science Studies (31), 21-43. doi:http://dx.doi.org/10.9761/JASSS2676

Akdoğan, E. (2002). Öğretim elemanlarının algıladıkları liderlik stilleri ile iş doyum düzeyleri arasindaki ilişki [The Relationship of the job satisfaction levels of lecturers and their percevied leadership styles]. [Unpublished Master's Thesis, Marmara University, İstanbul].

Amason, A. C. (1996). Distinguishing the effects of functional and dysfunctional conflict on strategic decision making: Resolving a paradox for top management teams. Academy of Management Journal, 39 (1), 123-148. 
Arslantaş, H. İ., \& Özkan, M. (2012). Okul müdürlerinin çatışma çözmede yapıcı yıkıcı olmaları ile öğretim liderliği arasındaki ilişki [The relationship between school principles' instructional leadership and their use of constructive and destructive dimensions of conflict management]. Dumlupınar Üniversitesi Sosyal Bilimler Dergisi (34), 231-240.

Avolio, B. J. (1994). The alliance of total quality and the full range of leadership. In M. Bass \& B. J. Avolio (Eds.), Improving organizational effectiveness through transformational leadership (pp. 121-145). Thousand Oaks, CA: Sage.

Ayda, N. K., Tumka, F., Tumkan, Ş., \& Ayda, O. (2020). Paternalist leadership in contemporary education strategies in conflict solution and management. Amazonia Investiga, 9 (30), 84-98.

Bass, B. M. (1985). Leadership and performance beyond expectations. New York: Free Press.

Bass, B. M. (1985). Leadership: Good, better, best. Organizational Dynamics, 13 (3), 26-40.

Bass, B. M. (1998). Transformational leadership: Industrial, military, and educational impact. Mahwah, NJ: Laurence Erlbaum.

Bass, B. M., \& Avolio, B. J. (1990). Developing transformational leadership: 1992 and beyond. Journal of European industrial Training, 14 (5), 21-27.

Bass, B. M., \& Avolio, B. J. (1994). Introduction. In B. M. Bass \& B. J. Avolio (Eds.), Improving organizational effectiveness through transformational leadership (pp. 1-10). Thousand Oaks, CA: Sage.

Can, A. (2014). SPSS ile bilimsel araştırma sürecinde nicel veri analizi [Quantitative data analysis in the scientific research process with SPSS]. Ankara: Pegem Akademi.

Champoux, J. E. (2020). Organizational behavior: Integrating individuals, groups, and organizations. New York: Routledge.

Chandolia, E., \& Anastasiou, S. (2020). Leadership and conflict management style are associated with the effectiveness of school conflict management in the region of epirus, NW Greece. European Journal of Investigation in Health, Psychology and Education, $10(1), 455-468$.

Cohen, J. (1988). Statistical power analysis for the behavioral sciences. Hillsdale, NJ: Lawrence Erlbaum Associates.

Creswell, J. W. (2012). Educational research: Planning, conducting, and evaluating quantitative. Boston: Pearson.

Çelik, K., \& Tosun, A. (2019). Okul yöneticilerinin çatışma yönetim stilleri ile örgütsel sağlık arasındaki ilişki [The relationship between school administrators' conflict management 
styles and organizational health]. Adlyaman Üniversitesi Ĕgitim Bilimleri Dergisi, 9 (1), 99-121. https://doi.org/10.17984/adyuebd.456709

Çiftci, D. Ö., \& Erkanlı, H. (2020). Liderlik yönelimlerinin çatışma çözme stratejileri üzerindeki etkisi [The impact of leadership orientations on conflict resolution strategies]. İşletme Araştırmalarl Dergisi, $12 \quad$ (4), 3930-3946. doi:https://doi.org/10.20491/isarder.2020.1081

Çimen, L. K., \& Sarıboğa, F. B. (2020). Okul müdürlerine ve öğretmenlerin algılarına göre çatışma yönetimi stillerinin bazı değiş̧kenler açısından incelenmesi [Examining school administrators' and teachers' conflict management styles according to their perception in terms of certain variables]. Akademik Sosyal Araştırmalar Dergisi, (110), 9-55. doi:http://dx.doi.org/10.29228/ASOS.46171

Dancey, C. P., \& Reidy, J. (2007). Statistics without maths for psychology. Harlow: Pearson Education.

De Dreu, C. K. W. (1997). Productive conflict: The importance of conflict management and conflict issue. In C. K. W. De Dreu \& E. Van de Vliert (Eds.), Using conflict in organizations (pp. 9-22). Sage Publications

Demirdağ, S. (2016). İlkokul yöneticilerinin etik liderlik davranışları ile çatışma yönetimi stratejileri arasındaki ilişki: Ücretli öğretmen görüşleri [The relationship between primary school administrators' ethical leadership and conflict management strategies: The perceptions of substitute teachers]. Turkish Studies (Elektronik), 11 (3), 879-894. http://dx.doi.org/10.7827/TurkishStudies.9250

Doğan, S. (2012). İlköğretim okulu yöneticilerinin liderlik stilleri ile kullandıkları çatışma çözüm stratejileri arasındaki ilişki [Relationship between leadership styles of the primary school principals and used the conflict resolution strategies]. Ĕgitim ve Öğretim Araştırmaları Dergisi, 1 (4), 226-233.

Donovan, M. M. (1993). Academic deans and conflict management: The relationship between perceived styles and effectiveness of managing conflict. [Unpublished Doctoral Thesis, Marquette University].

Ermeydan, M., \& Can, N. (2020). Okul yöneticilerin liderlik stilleriyle etkili okul arasındaki ilişki [The relationship between school leaders' leadership styles and school effectiveness]. Gaziantep Üniversitesi Ĕ̆itim Bilimleri Dergisi, 4 (2), 94-121.

Field, A. (2005). Discovering statistics using SPSS. London: Sage Publication.

Geçmez, T. (2009). Yöneticilerin dönüşümcü ve etkileşimci liderlik stilleri ile çatışma yönetimi stilleri arasındaki ilişki ve kimya sektöründe bir araştırma [The relationship between 
transformational and transactional leadership styles of managers and conflict management styles and a research in the chemical industry. [Unpublished Master Thesis, Marmara University].

Gordon, J. R. (1996). Organizational behavior: A diagnostic approach. New Jersey:Prentice Hall.

Gül, İ., \& Türkmen, F. (2018). Öğretmen görüşlerine göre okul yöneticilerinin farklılıkların yönetimi ve çatışma çözme becerilerinin incelenmesi [Investigation of administration and conflict resolution skills of differences of school administrators by teacher's vision]. Turkish Studies (Elektronik), 13 (4), 649-668.

Gümüşeli, A. İ. (1994). İzmir ortaöğretim okulları yöneticilerinin ögretmenler ile aralarındaki çatışmaları yönetme biçimleri. [Unpublished Doctoral Thesis, Ankara University].

Hanson, E. M. (1996). Educational administration and organizational behavior. Boston: Allyn and Bacon.

Hoy, W. K., \& Miskel, C. G. (2005). Educational administration: Theory, research, and practice. New York: McGraw-Hill.

Hussein, A. F. F., \& Al-Mamary, Y. H. S. (2019). Conflicts: Their types, and their negative and positive effects on organizations. International Journal of Scientific \& Technology Research, 8 (8), 10-13.

Jehn, K. A., \& Bendersky, C. (2003). Intragroup conflict in organizations: A contingency perspective on the conflict-outcome relationship. Research in Organizational Behavior, $25,187-242$.

Jehn, K. A., Northcraft, G. B., \& Neale, M. A. (1999). Why differences make a difference: A field study of diversity, conflict and performance in workgroups. Administrative Sscience Quarterly, 44 (4), 741-763.

Jit, R., Sharma, C. S., \& Kawatra, M. (2016). Servant leadership and conflict resolution: A qualitative study. International Journal of Conflict Management, 27 (4), 591-612. Doi: 10.1108/IJCMA-12-2015-0086

Jung, D. I. (2001). Transformational and transactional leadership and their effects on creativity in groups. Creativity Research Journal, 13 (2), 185-195.

Karip, E. (2013). Çatışma yönetimi [Conflict management]. Ankara: Pegem Akademi.

Kavrayıcı, C. (2019). Okul müdürlerinin liderlik stillerinin çeşitli değişkenler açısından incelenmesi [Examination of leadership styles of school pricinples in terms of different variables]. Anadolu Üniversitesi Eğitim Fakültesi Dergisi, 3 (2), 116-131, https://doi.org/10.34056/aujef.518248 
Kolb, D. M., \& Putnam, L. L. (1992). The multiple faces of conflict in organizations. Journal of Organizational Behavior, 13 (3), 311-324.

Konak, M., \& Erdem, M. (2015). Öğretmenlerin görüşlerine göre ilkokul yöneticilerinin etik liderlik davranışları ile çatışma yönetme stratejileri arasındaki ilişki [According to the teachers' opinions the relationship between the ethical leadership behaviors of the elementary school principals and their conflict management strategies]. Kuram ve Uygulamada Egitim Yönetimi Dergisi, 21 (1), 69-91. doi: 10.14527/kuey.2015.004

Korkmaz, M., \& Çağlı, M. (2019). Eğitim yöneticilerinin liderlik tarzları ile çatışma yönetim stratejileri arasındaki ilişkinin incelenmesi [The relationship between leadership styles and conflict management strategies of an education managers]. TURAN-SAM, 11 (41), $77-90$.

Kuhnert, K. W. (1994). Transforming leadership: Developing people through delegation. In B. M. B. Bass \& B. J. Avolio (Eds.), Improving organizational effectiveness through transformational leadership (pp. 10-25). California: Sage.

Küçüksüleymanoğlu, R., \& Bingöl, A. (2014). Ortaöğretim kurumlarında görev yapan öğretmenlerin görüşlerine göre okul yöneticilerinin çatışma yönetimi yöntemlerinin incelenmesi [An investigation of conflict management styles of the high school administrators perceived by the teachers]. Route Educational and Social Science Journal, 1 (2), 39-53.

Lunenburg, F. C., \& Ornstein, A. (2021). Educational administration: Concepts and practices. California: SAGE Publications.

Mishra, P., \& Dhar, U. (2002). Leveraging functional conflicts. Indian Journal of Industrial Relations, 38 (1), 113-119.

Morgan, G. A., Leech, N., \& Barret, K. (2005). SPSS for intermediate statistics: Use and interpretation. New York: Lawrence Erlbaum Associates.

Msila, V. (2012). Conflict management and school leadership. Journal of Communication, 3 (1), 25-34.

Okçu, V., Dogan, E., \& Dayanan, İ. (2016). İlk ve ortaokul öğretmenlerinin algılarına göre okul yöneticilerinin iletişim becerileri ile çatışma yönetim stilleri arasındaki ilişkinin incelenmesi [Examining the relationship between communication skills and conflict management styles of school administrators according to perceptions of primary and secondary school teachers]. Kuram ve Uygulamada Eğitim Yönetimi, 22 (2), 217-244.

Okçu, V., Doğan, E., \& Dayanan, İ. (2018). Öğretmenlerin okul kültürü algılarının okul yöneticilerinin çatışma yönetimi stilleri üzerindeki etkisi (Şırnak ili örneği) [The effect 
of teachers' perceptions related to school culture on conflict management styles of school principals (Şırnak province sample)]. Anadolu Ĕgitim Liderliği ve Öğretim Dergisi, 6 (2), 41-62.

Önk, M., \& Cemaloğlu, N. (2016). İlköğretim kurumu yöneticilerin liderlik tarzları ile çatışmayı yönetme stratejileri arasındaki ilişki Ankara ili örneği. Pegem Atıf Indeksi, 829-862. Doi: http://dx.doi.org/10.14527/9786053183563.053

Örs, H., \& İlgar, M. Z. (2019). Okul yöneticilerinin otantik liderlik ve çatışma yönetimi stratejileri arasındaki ilişkinin incelenmesi [Relationship between the authentic leadership and conflict management strategies for school principals]. Anadolu Ĕ̈itim Liderliği ve Öğretim Dergisi, 7 (2), 1-18.

Polatc1, S., \& Sobac1, F. (2017). Dönüşümcü ve etkileşimci liderlerin çatışma yönetim strateji tercihlerinin incelemesi: Türkiye genelinde bir araştırma [Investigation of conflict management strategy preferences of the transformational and transactional leaders': A research in Turkey. Ömer Halisdemir Üniversitesi İktisadi ve İdari Bilimler Fakültesi Dergisi, 10 (3), 27-40. https://doi.org/10.25287/ohuiibf.310166

Rahim, M. A. (1983). Rahim organizational conflict inventory: Forms A, B, and C. California: Consulting Psychologists Press.

Rahim, M. A. (2001). Managing conflict in organizations. Connecticut: Quorum Books.

Rahim, M. A. (2002). Toward a theory of managing organizational conflict. International Journal of Conflict Management. 13 (3), 206-235. https://doi.org/10.1108/eb022874

Rahim, M. A. (2017). Social intelligence, power, and conflict: Volume 17: Current topics in management. Londres: Routledge.

Robbins, S. P. (1974). Managing organizational conflict: A nontraditional approach: New Jersey: Prentice-Hall.

Robbins, S. P. (1998). Organizational behavior: Concepts, controversies, applications. New Jersey: Prentice Hall

Saeed, T., Almas, S., Anis-ul-Haq, M., \& Niazi, G. (2014). Leadership styles: Relationship with conflict management styles. International Journal of Conflict Management. 25 (3), 214 225. doi: 10.1108/IJCMA-12-2012-0091

Sorenson, R. L. (1999). Conflict management strategies used by successful family businesses. Family Business Review, 12 (4), 325-340.

Şanlı Güneş, E. N., \& Akbaba, A. (2020). İlk ve ortaokul yöneticilerinin çatışma yönetimi stilleri ile benlik saygısı arasındaki ilişkinin incelenmesi [Examining the relationship 
between conflict management styles and self-esteem of primary and secondary school administrators]. Manas Sosyal Araştırmalar Dergisi, 9 (3), 1410-1425.

Şirin, E. F. (2008). Beden eğitimi ve spor yüksekokulu yöneticilerinin liderlik stilleri ve çatışma yönetimi stratejilerinin incelenmesi [Leadership styles of physical education and sports school managers and study of conflict management strategies]. [Unpublished Doctoral Thesis, Gazi University].

Tabachnick, B. G., \& Fidell, L. S. (2013). Using multivariate statistics. Boston: Pearson.

Titrek, O., Maral, M., \& Barut Kızılkaya, D. (2015). Öğretmen görüşlerine göre ilköğretim okul yöneticilerinin kullandıkları çatışma yönetimi stratejileri [Investigating primary school teachers' perception of conflict management strategies used by principals]. International Journal of Human Sciences, 12 (2), 1734-1755. doi:10.14687/ijhs.v12i2.3504

Tosi, H. L., Rizzo, J. R., \& Carroll, S. J. (1994). Managing organizational behavior. Oxford: Blackwell.

Yukl, G. (2013). Leadership in organizations. Harlow: Pearson Education.

Zhang, X.-a., Cao, Q., \& Tjasvold, D. (2011). Linking transformational leadership and team performance: A conflict management approach. Journal of Management Studies, 48, 1586-1611. doi: 10.1111/j.1467-6486.2010.00974.x 